\title{
Genetic structure in natural populations of Dacrydium elatum (Roxb.) Wall. (Podocarpaceae) in the Central Highlands of Vietnam inferred by Microsatellites
}

\author{
Dinh Duy $\mathrm{Vu}^{1 *}$, Quoc Khanh Nguyen ${ }^{1}$ and Mai Phuong Pham ${ }^{1}$ \\ Institute of Tropical Ecology, Vietnam - Russia Tropical Center, 63 Nguyen Van Huyen, Ha Noi, \\ Vietnam
}

\begin{abstract}
To provide a reference for the conservation and application of breeding parentallines resource of Dacrydium elatum (Roxb.). Genetic diversity and population structure of eighty individuals from four populations (Kon Tum, Gia Lai, Dak Lak and Lam Dong) in Central Highlands were evaluated using eight SSR markers. Based on the SSR data, 21 alleles were detected by eight SSR with high polymorphism. The genetic diversity of levels within the populations were moderately high (Ho $=0.555, \mathrm{He}=0.429)$. The average number of shannon information index were 0.618 and genetic differentiation among populations was low (Fst $=0.097)$. The AMOVA revealed high genetic variation within individuals (87\%) compared among populations (13\%). The UPGMA phenogram showed that the results of molecular clustering largely agreed with the pedigree and geographic origin. Three populations (NL, KCR and BDNB) were clustered together and CYS population was separated. The maximum quantity $\Delta \mathrm{K}$ was observed for $\mathrm{K}=2$ in population structure analysis, indicating that the entire collection could be divided into two main groups of genes. This study can provide a theoretical basis for genetic resource management and varieties identification of $D$. elatum resources, and provide reference basis for breeding.
\end{abstract}

\section{Introduction}

Dacrydium elatum (Roxb.) Wall. genus Dacrydium (Podocarpaceae) isconifer species in Vietnam, grows in primary closed evergreen seasonal forest tropical mixed (elevations $700-2000 \mathrm{~m}$ ) they have been extensively used for furniture, handicrafts and construction [13]. In Vietnam it is found in Ha Giang, Tuyen Quang, Quang Ninh, Lai Chau, Ha Tinh, Quang Binh, Thua Thien Hue, Da Nang, Kon Tum, Gia Lai, Dak Lak, Lam Dong and Kien Giang provinces and other countries like China, Laos, Cambodia, Thailand, Malaysia and

\footnotetext{
*Corresponding author: dinhduyvu87@gmail.com
} 
Indonesia [1-2]. D. elatum has been classified as an endangered species and put strictly on the conservation list as Vulnerable (VU) [1]. Up to now, many populations of D. elatum are endangered by over exploitation and deforestation and we have serious lack of information on ecological characteristics and genetic variation at population and species levels of $D$. elatum, especially the negative effects of human activities. This situation urged to undertake a study to address these problem and to provide additional information for the Forest Protection Department in order to stress the need for the conservation and sustainable use of the species of local communities.

Conservation and management of a species require information on the ecological and genetic diversity within and among it's populations [4-6]. To develop appropriate conservation strategies, microsatellite markers (simple sequence repeats, SSR) are commonly used to assess the levels of genetic diversity and genetic structure, both at population and species level [4, 7]. SSR has the advantages of high polymorphism, codominant inheritance, and widespread presence in the entire genome [8]. It isideal marker to probe genetic diversity and population structure and has a broad application scope [910]. Many SSR markers were developed and have been widely used to probe genetic diversity within and among conifer populations [11-13]. Previous studies investigated the genetic variation and verified the taxonomic status of the Dacrydium species at the molecular level, such as D. pectinatum [14], D. imbricatus [15], D. elatum [16], however the genetic structure of $D$. elatum has not been explored in Vietnam. Meanwhile, knowing genetic diversity is important for the development of conservation strategies and the sustainable utilization of thisspecies [6,17]. Therefore, it is a dire need of the day to explore the diversity and population structure of $D$. elatum and set breeding and conservation strategies.

The main goal of the current study was to determine level of genetic diversity and genetic structure of natural populations of D. elatum in the Central Highlands of Vietnam, and to provide guidelines for the conservation, management, and restoration of the species.

\section{Materials and Methods}

\subsection{Sample collection}

A total of 80 plant samples (leaf) were randomly collected from four populations in the Central Highlands of Vietnam (Table 1; Figure 1). The samples were immediately placed in liquid nitrogen, transferred to the molecular laboratory of Vietnam-Russia Tropical Centre and stored at $-80^{\circ} \mathrm{C}$ until DNA extraction.

Table 1. Sampling location of D. elatum in the Central Highlands of Vietnam

\begin{tabular}{|c|c|c|c|c|c|}
\hline $\begin{array}{c}\text { Population } \\
\text { code }\end{array}$ & Region & $\begin{array}{c}\text { Sample } \\
\text { size }\end{array}$ & $\begin{array}{c}\text { Latitude } \\
(\mathrm{N})\end{array}$ & $\begin{array}{c}\text { Longitude } \\
\text { (E) }\end{array}$ & $\begin{array}{c}\text { Altitude } \\
\text { (m) }\end{array}$ \\
\hline NL & $\begin{array}{l}\text { Ngoc Linh Nature Reserve, } \\
\text { Kon Tum province }\end{array}$ & 20 & $14^{0} 38^{\prime} 27^{\prime \prime}$ & $108^{0} 24^{\prime} 35^{\prime \prime}$ & 1211 \\
\hline CYS & $\begin{array}{l}\text { Chu Yang Sin national } \\
\text { park, Đak Lak province }\end{array}$ & 20 & $12^{\circ} 24^{\prime} 47^{\prime \prime}$ & $108^{\circ} 23^{\prime} 03^{\prime \prime}$ & 1296 \\
\hline BDNB & $\begin{array}{l}\text { Bidoup-Nui } \mathrm{Ba} \text { national } \\
\text { park, Lam Dong province }\end{array}$ & 20 & $12^{\circ} 10^{\prime} 57^{\prime \prime}$ & $108^{\circ} 41^{\prime} 32^{\prime \prime}$ & 1471 \\
\hline KCR & $\begin{array}{l}\text { Kon Chu Rang Nature } \\
\text { Reserve, Gia Lai province }\end{array}$ & 20 & $14^{\circ} 31^{\prime} 10^{\prime \prime}$ & $108^{\circ} 32^{\prime} 46^{\prime \prime}$ & 1001 \\
\hline
\end{tabular}



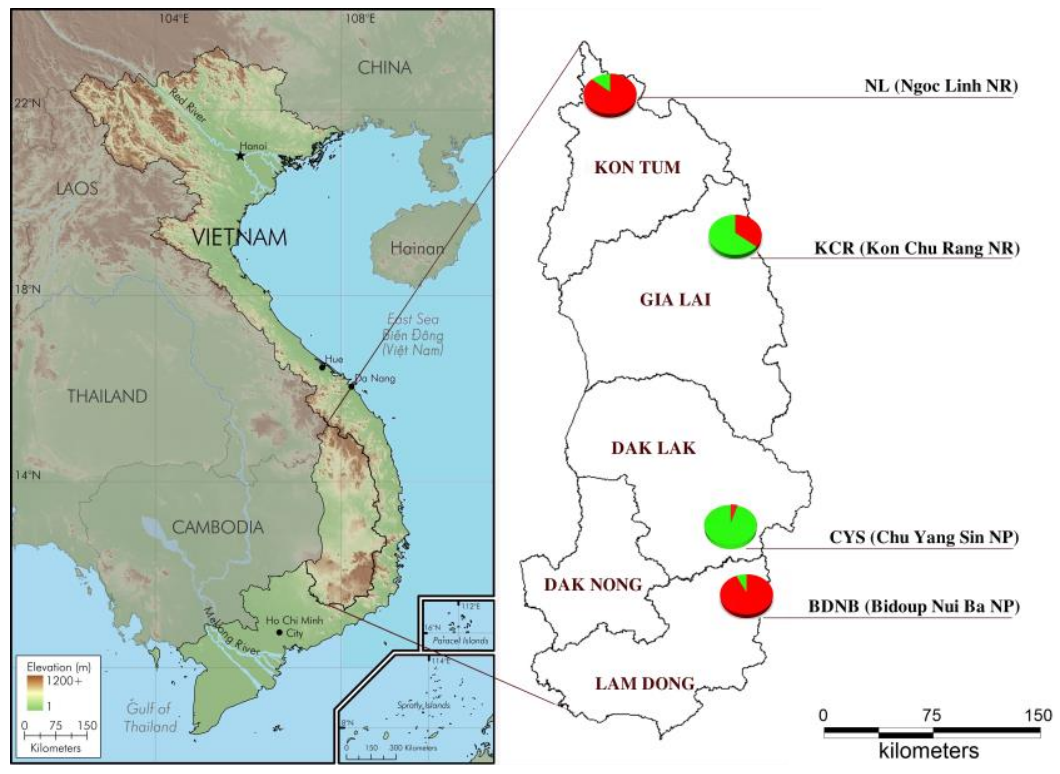

Fig 1. Map showing the study location of D. elatum in the Central Highlands of Vietnam

\subsection{DNA extraction}

Total genomic DNA was extracted using the plant/fungi DNA isolation Kit (Norgenbiotek, Canada). The total DNA purity and integrity were tested by Nanodrop ND-2000 spectrophotometer (NanoDrop Technologies, DE, USA) and then diluted to a concentration of $10 \mathrm{ng} / \mu 1$

\subsection{Microsatellite amplification}

PCR-SSR was performed in a $25 \mu \mathrm{L}$ reaction mixture containing (20ng genomic DNA, Dreamtaq Master Mix (2X), 10 pmol of each primer, and $\mathrm{H}_{2} \mathrm{O}$ deionised). The PCR-SSR were performed in $\mathrm{C} 1000$ Touch Thermal Cycler as follows: an initial denaturing step at $94^{\circ} \mathrm{C}$ for $3 \mathrm{~min}, 35$ cycles $\left(94^{\circ} \mathrm{C} / 60 \mathrm{~s}, 55^{\circ} \mathrm{C} / 30 \mathrm{~s}\right.$ and $\left.72^{\circ} \mathrm{C} / 60 \mathrm{~s}\right)$ and $10 \mathrm{~min}$ at $72^{\circ} \mathrm{C}$ for the final cycle to complete the extension of any remaining products before holding the samples at $4^{\circ} \mathrm{C}$ until they were analyzed. Eight pairs of primers (SSR) were selected (Table 2). The amplification products were separated using a Sequi-Gen ${ }^{\circledR}$ GT DNA electrophoresis system $8 \%$ polyacrylamide gels in $1 \mathrm{x}$ TAE buffer and then visualized by GelRed 10.000X. The sizes of the PCR products were detected and analyzed using GelAnalyzer software of with a 20 bp DNA ladder (Invitrogen, USA).

Table 2. Information of nine SSR markers for PCR amplification in D. elatum

\begin{tabular}{|c|c|c|c|c|c|}
\hline Locus & Primer sequence (5'-3') & Repeat motif & $\begin{array}{c}\text { PCR } \\
\text { product } \\
\text { (bp) }\end{array}$ & $\begin{array}{l}\text { Tm } \\
\left({ }^{0} \mathrm{C}\right)\end{array}$ & $\begin{array}{l}\text { Sourc } \\
\text { es }\end{array}$ \\
\hline SSR1 & $\begin{array}{l}\text { F: GAGACCAGACAAAGATGAAGA } \\
\text { R: GAGTAAGAGCAAGACACCAAA }\end{array}$ & $(\mathrm{AG}) 21$ & $190-200$ & 55 & {$[11]$} \\
\hline SSR2 & $\begin{array}{l}\text { F: GGCATTGGCTCAACAGA } \\
\text { R: TCGTGGAGAGGTACTTCATT }\end{array}$ & $(\mathrm{CT}) 9$ & $160-180$ & 55 & {$[11]$} \\
\hline SSR3 & $\begin{array}{l}\text { F: GCCAGGGAAAATCGTAGG } \\
\text { R: AGAAGATTAGACATCCAACCC }\end{array}$ & $(\mathrm{T})_{14}(\mathrm{~T})_{10} \mathrm{C}(\mathrm{T})_{5}$ & $140-160$ & 55 & {$[17]$} \\
\hline SSR4 & F: CCCGTATCCAGATATACTTCCA & $(\mathrm{T})_{14}(\mathrm{~T})_{11}$ & $150-200$ & 55 & [17] \\
\hline
\end{tabular}




\section{R: TGGTTTGATTCATTCGTTCAT}

\begin{tabular}{clcccc}
\multirow{2}{*}{ SSR5 } & $\begin{array}{l}\text { F: AATGAAAGGCAAGTGTCG } \\
\text { R: GAGATGCAAGATAAAGGAAGTT }\end{array}$ & $(\mathrm{GGT}) 10$ & $200-220$ & 55 & {$[18]$} \\
\multirow{2}{*}{ SSR6 } & $\begin{array}{l}\text { F: ATCCTGAGTCCCTGTATGTT } \\
\text { R: CTACTATCTGAGCACGCCAC }\end{array}$ & $(A G) 18$ & $220-240$ & 55 & {$[12]$} \\
\multirow{2}{*}{ SSR7 } & $\begin{array}{l}\text { F: TCCAAGGATGCACATTCAAT } \\
\text { R: AAACAAAACCTCACTCAATGAA }\end{array}$ & $(A C) 18$ & $200-220$ & 55 & {$[12]$} \\
SSR8 & $\begin{array}{l}\text { F: AAACAAAACCTCACTCAATGAA } \\
\text { R: CCCACTTCCTCCAGCAATAC }\end{array}$ & $($ AC) $37(\mathrm{AG}) 22$ & $120-130$ & 55 & {$[12]$} \\
\hline
\end{tabular}

\subsection{Data analysis}

The software GENALEX ver.6.5 [20] was used to calculate the characterization and polymorphism level of 8 SSR loci including the number of alleles per locus $(\mathrm{Na})$, number of effective alleles $(\mathrm{Ne})$, Shannon-Weiner index $(I)$, the observed heterozygosities $\left(H_{o}\right)$, the expected heterozygosities $\left(H_{e}\right)$ and the genetic differentiation for all populations ( $\left.\mathrm{F}_{\mathrm{ST}}\right)$. Tests of deviation from the Hardy-Weinberg equilibrium per locus in each population were performed at a significance level of 0.05, using GENEPOP v4.6 [21]. The analysis of molecular variance (AMOVA) of data was calculated by Arlequin 3.1 [22]. The genetic association amongst populations was determined by Poptree 2 using the UPGMA approach [23]. The population structure was explored by STRUCTUREv.2.3.4 [24]. The targeted population was separated into groups by Structure Harvester [25] based on the $\Delta \mathrm{K}$ by Evanno et al. [26].

\section{Results}

\subsection{Genetic diversity}

Eight SSR primer pairs amplified consistently under standard conditions, clear products and were used to assess the population genetic structure. All primers were submitted to amplification cycles with primer annealing at $55^{\circ} \mathrm{C}$. All of SSR markers were polymorphic in four D. elatum populations. A total of 21 different alleles wererecorded for D. elatum. Genetic diversity of each population wasshowed in Table 3 . The number of observed alleles $(\mathrm{Na})$ and the effective number of alleles $(\mathrm{Ne})$ varied from 2 to 3 and from 1.755 to 1.924 , respectively. Shannon-Weiner index $(I)$ ranged from 0.57 in NL population to 0.684 in BDNB population with an average of 0.618 . The average observed heterozygosity $\left(H_{O}\right)$ and expected heterozygosity $\left(H_{e}\right)$ were $0.555 \quad(0.563-0.615)$ and 0.429 (0.398-0.467), respectively. Interestingly, there were also differences in the ratios of genetic diversity between four populations (NL, CYS, BDNB, and KCR). Among the four populations, population of BDNB $\left(\mathrm{H}_{\mathrm{O}}=0.684\right.$ and $\left.\mathrm{H}_{\mathrm{e}}=0.588\right)$ was the highestgenetic diversity. Three locus (SSR4, SSR5 and SSR7) showed significant deviations from the Hardy-Weinberg equilibrium in populations NL, CYS, BDNB, and KCR, respectively.

Table 3. Polymorphism of eight SSR markers and the Hardy-Weinberg equilibrium testing for each population of D. elatum

\begin{tabular}{|c|c|c|c|c|c|c|c|c|c|c|c|c|}
\hline & \multicolumn{6}{|c|}{ NL population $(\mathrm{N}=20)$} & \multicolumn{6}{|c|}{ CYS population $(\mathrm{N}=20)$} \\
\hline & $\mathbf{N a}$ & $\mathrm{Ne}$ & I & Но & He & $\begin{array}{c}\text { HWE } \\
\text { P- } \\
\text { value }\end{array}$ & $\mathbf{N a}$ & $\mathrm{Ne}$ & $\mathbf{I}$ & Ho & He & $\begin{array}{c}\text { HWE } \\
\text { P- } \\
\text { value }\end{array}$ \\
\hline $\begin{array}{l}\text { SSR1 } \\
\text { SSR? }\end{array}$ & 2.000 & 1.994 & 0.692 & 0.833 & 0.498 & $0.004^{* *}$ & 3.000 & $\begin{array}{l}1.590 \\
2.000\end{array}$ & $\begin{array}{l}0.639 \\
0.693\end{array}$ & $\begin{array}{l}0.200 \\
0.467\end{array}$ & $\begin{array}{l}0.371 \\
0.500\end{array}$ & $\begin{array}{l}0.159^{\mathrm{ns}} \\
0.796^{\mathrm{ns}}\end{array}$ \\
\hline SSR2 & 2.000 & 1.800 & 0.637 & 0.111 & 0.444 & $0.001^{* *}$ & 2.000 & 2.000 & 0.693 & 0.467 & 0.500 & $0.796^{\text {ns }}$ \\
\hline
\end{tabular}




\begin{tabular}{|c|c|c|c|c|c|c|c|c|c|c|c|c|}
\hline SSR3 & 2.000 & 1.180 & 0.287 & 0.167 & 0.153 & $0.700^{\text {ns }}$ & 2.000 & 2.000 & 0.693 & 1.000 & 0.500 & $0.000^{* * * *}$ \\
\hline SSR4 & 2.000 & 2.000 & 0.693 & 1.000 & 0.500 & $0.000^{* * *}$ & 2.000 & 2.000 & 0.693 & 1.000 & 0.500 & $0.000^{* * * *}$ \\
\hline SSR5 & 2.000 & 2.000 & 0.693 & 1.000 & 0.500 & $0.000^{* * *}$ & 2.000 & 2.000 & 0.693 & 1.000 & 0.500 & $0.000^{* * *}$ \\
\hline SSR6 & 2.000 & 1.117 & 0.215 & 0.111 & 0.105 & $0.803^{\text {ns }}$ & 2.000 & 1.965 & 0.684 & 0.200 & 0.491 & $0.022^{*}$ \\
\hline SSR7 & 2.000 & 2.000 & 0.693 & 1.000 & 0.500 & $0.000^{* * *}$ & 2.000 & 2.000 & 0.693 & 1.000 & 0.500 & $0.000^{* * *}$ \\
\hline SSR8 & 2.000 & 1.946 & 0.679 & 0.278 & 0.486 & $0.069^{\mathrm{ns}}$ & 1.000 & 1.000 & 0.000 & 0.000 & 0.000 & n.a \\
\hline \multirow[t]{3}{*}{ Mean } & 2.000 & 1.755 & 0.574 & 0.563 & 0.398 & & 2.000 & 1.819 & 0.599 & 0.608 & 0.420 & \\
\hline & \multicolumn{6}{|c|}{ BDNB population $(\mathrm{N}=\mathbf{2 0})$} & \multicolumn{6}{|c|}{ KCR population $(\mathrm{N}=\mathbf{2 0})$} \\
\hline & $\mathbf{N a}$ & $\mathrm{Ne}$ & I & Ho & He & $\begin{array}{c}\text { HWE } \\
\text { P- } \\
\text { value }\end{array}$ & $\mathbf{N a}$ & $\mathrm{Ne}$ & I & Но & He & $\begin{array}{c}\text { HWE } \\
\text { P- } \\
\text { value }\end{array}$ \\
\hline SSR1 & 2.000 & 1.940 & 0.677 & 0.471 & 0.484 & $0.906^{\mathrm{ns}}$ & 2.000 & 1.956 & 0.682 & 0.250 & 0.489 & $0.029^{*}$ \\
\hline SSR2 & 2.000 & 1.778 & 0.630 & 0.294 & 0.438 & $0.176^{\mathrm{ns}}$ & 2.000 & 1.280 & 0.377 & 0.150 & 0.219 & $0.160^{\text {ns }}$ \\
\hline SSR3 & 2.000 & 1.710 & 0.606 & 0.588 & 0.415 & $0.086^{\mathrm{ns}}$ & 2.000 & 2.000 & 0.693 & 1.000 & 0.500 & $0.000^{* * *}$ \\
\hline SSR4 & 2.000 & 2.000 & 0.693 & 1.000 & 0.500 & $0.000^{* * *}$ & 2.000 & 2.000 & 0.693 & 1.000 & 0.500 & $0.000^{* * *}$ \\
\hline SSR5 & 2.000 & 2.000 & 0.693 & 1.000 & 0.500 & $0.000^{* * *}$ & 2.000 & 2.000 & 0.693 & 1.000 & 0.500 & $0.000^{* * * *}$ \\
\hline SSR6 & 2.000 & 1.410 & 0.466 & 0.118 & 0.291 & $0.014^{*}$ & 2.000 & 1.923 & 0.673 & 0.100 & 0.480 & $0.000^{* * *}$ \\
\hline SSR7 & 2.000 & 2.000 & 0.693 & 1.000 & 0.500 & $0.000^{* * *}$ & 2.000 & 1.724 & 0.611 & 0.100 & 0.420 & $0.001^{* * * *}$ \\
\hline SSR8 & 3.000 & 2.558 & 1.018 & 0.235 & 0.609 & $0.000^{* * *}$ & 2.000 & 1.471 & 0.500 & 0.100 & 0.320 & $0.002^{* *}$ \\
\hline \multirow[t]{2}{*}{ Mean } & 2.125 & 1.924 & 0.684 & $\mathbf{0 . 5 8 8}$ & 0.467 & & 2.000 & 1.794 & 0.615 & 0.463 & 0.428 & \\
\hline & \multicolumn{12}{|c|}{ Genetic diversity of four D. elatum populations } \\
\hline $\begin{array}{l}\text { Total } \\
\text { mean }\end{array}$ & 2.031 & 1.823 & 0.618 & 0.555 & 0.429 & & & & & & & \\
\hline
\end{tabular}

\subsection{Population structure}

It can be seen from the data in Table 4 that analysis of molecular variance (AMOVA) was performed based on 279.643 permutation. The AMOVA showed that total variation was highly significant $(\mathrm{p}<0.001)$ within individuals $(87 \%)$, and among populations $(13 \%)$ (Table 4).

Table 4. Analysis of molecular variance in D. elatum from 4 populations

\begin{tabular}{lccccc}
\hline \multicolumn{1}{c}{ Source of variation } & df & $\begin{array}{c}\text { Sum of } \\
\text { squares }\end{array}$ & $\begin{array}{c}\text { Variance } \\
\text { components }\end{array}$ & $\begin{array}{c}\text { Total } \\
\text { variation (\%) }\end{array}$ & P value \\
\hline Among populations & 3 & 39.769 & 0.343 & $13 \%$ & \\
Among individuals & 76 & 85.874 & 0.000 & $0 \%$ & $<0.001$ \\
within populations & 80 & 154.000 & 2.200 & $87 \%$ & \\
$\begin{array}{l}\text { Within individuals } \\
\quad \text { Total }\end{array}$ & 159 & 279.643 & 2.543 & $100 \%$ & \\
\hline
\end{tabular}

Genetic variation within populations was recorded as 0.097 (0.067-0.166) indicating low genetic differentiation. The highest differentiation value $\left(\mathrm{F}_{\mathrm{ST}}=0.166\right)$ was between the two populations of NL/CYS and low $\left(\mathrm{F}_{\mathrm{ST}}=0.067\right)$ between NL/BDNB (Table 5).

Table 5. Population pairwise $F_{S T}$ in D. elatum

\begin{tabular}{lcccc}
\hline & NL & BDNB & CYS & KCR \\
\hline NL & - & & & \\
BDNB & 0.067 & - & & \\
CYS & 0.166 & 0.109 & - & \\
KCR & 0.086 & 0.072 & 0.084 & - \\
\hline
\end{tabular}

The result of unweighted pair group method analysis (UPGMA) tree constructed on the basis of Nei's distance using POPTREE, which showed that other groups were separated 
clearly at population level (Fig. 2). Two different groups were generated; the $1^{\text {st }}$ group was contains 3 populations (NL, KCR and BDNB) with a bootstrap value of $100 \%$. This main group divided into two subgroups. Sub-clusters 1 included two population (NL and KCR) were clustered together with a bootstrap value of $62 \%$ and sub-clusters 2 only have BDNB population were separated. And the second major was composed of CYS population.

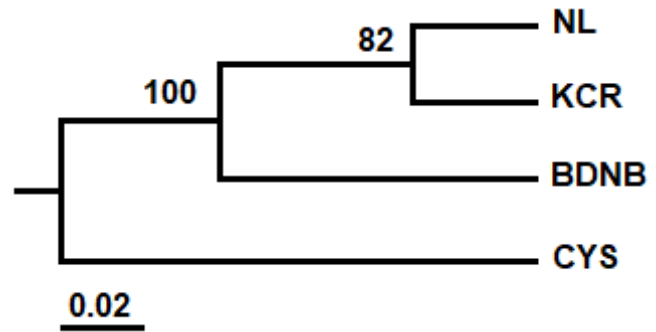

Figure 2. UPGMA dendrogram based on Nei's chord distance of genetic relationship among four $D$. elatum populations
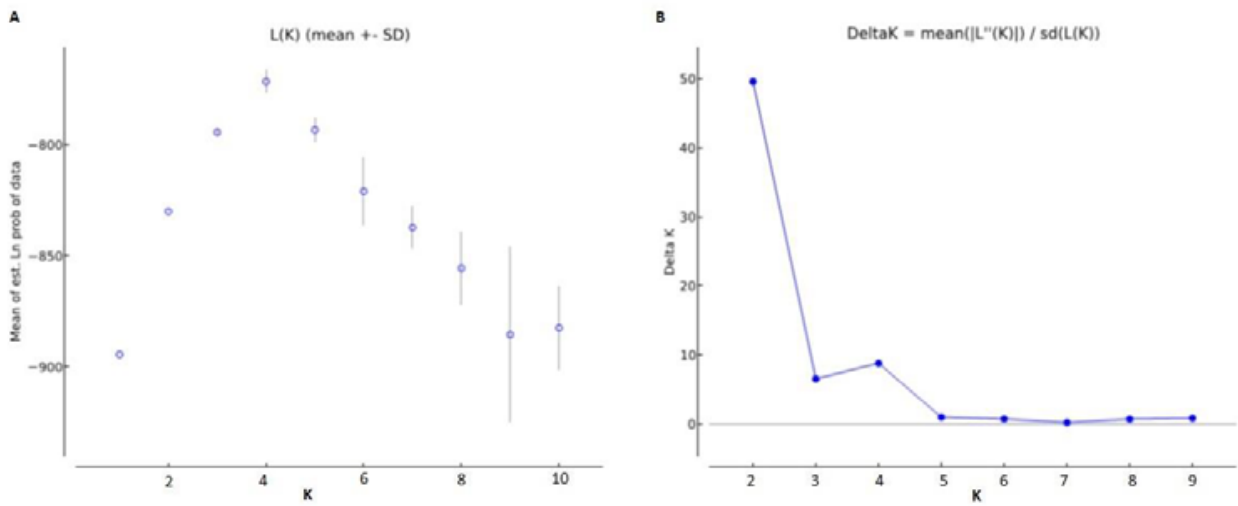

Figure 3. Plot of the $\operatorname{Ln} \mathrm{P}(\mathrm{D}) \pm \mathrm{SD}$ and delta K (DK). A. The mean of $\mathrm{LnP}(\mathrm{D})$ was based on 10 repetitions for each $K$ value. B. Plot of $\Delta K$ according to $K$.

We were performed population structure analysis, the highest $\Delta K$ value (49.63), have a clear peak for 80 individuals when $K=2$ to be the optimum number of genetic clusters and indicated that all the studied plants exhibited admixture from two clusters (Fig. 4). One group (red) was predominant in the two populations (NL and BDNB) with strong ancestry values $86.8 \%$ and $93 \%$, respectively and the second group (green) was composed of two populations (CYS and KCR) with strong ancestry values $95.4 \%$ and $63.6 \%$, respectively (Table 6; Fig. 1\&4). In particular, 4 D. elatum populations in Central Highlands of Vietnam showed a rich a rich mixture of ancestral genes among individuals.

Table 6. Percentage of ancestry for four D. elatum populations was analyzed from Structure Harvester

\begin{tabular}{rcc}
\hline \multirow{2}{*}{ Populations code } & \multicolumn{2}{c}{ Genetic group } \\
\cline { 2 - 3 } & Cluster 1 (\%) (Red) & Cluster 2 (\%) (Green) \\
\hline BDNB & 86.8 & 13.2 \\
CYS & 93.0 & 7.0 \\
KCR & 4.6 & 95.4 \\
\end{tabular}




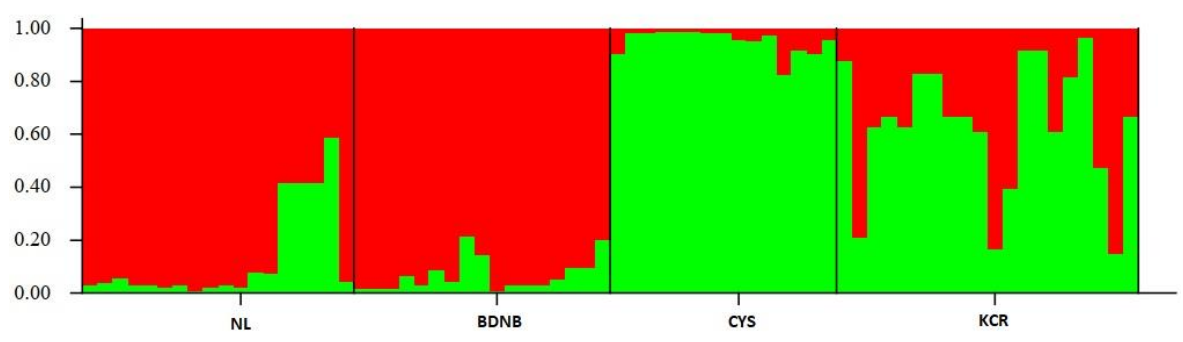

Figure 4. Bar plot of admixture assignment for 4 D. elatum populations to cluster $(\mathrm{K}=2$, highest $\Delta \mathrm{K}$ value $=49.63$ ) based on Bayesian analysis

\section{Discussion}

In the current study, all the 8 SSR loci were highly polymorphic in the 80 genotypes with a mean value of 2.031 alleles per locus, the mean number of effective alleles $(\mathrm{Ne}=1.823)$. The genetic diversity level was moderately high with $H_{O}=0.555$ and $H_{e}=0.429$. Ho $>\mathrm{He}$ were detected of four populations in the present study, suggesting that these populations are predominantly allogamic, which might be a result of outcrossing and reflecting the population structures. Although, it has previously been studied on the genetic diversity of D. elatum.. Tran et al. [16] had compared the effectiveness between ISSR and SSR markers in assessing genetic diversity of natural populations of D. elatum in Tay Nguyen, Vietnam and show that high level of genetic variation of D. elatum $(\mathrm{He}=0.301)$. This result was consistent with the study of Tran et al. [16]. Several reports have shown that high genetic diversity in other conifer using SSR markers [11, 12, 27-32] However, low of genetic diversity were found in prior studies $[4,33,34]$. Our investigations confirm the suggestion that the genetic structure of natural populations of $D$. elatum was strongly affected by population sizes. Which a lot of individuals remaining in the natural forest from 100 individuals in KCR and NL populations to about 500 in BDNB and CYS populations. All of studied populations were found in the secondary forests at more than $1000 \mathrm{~m}$ elevations. Forests have been greatly fragmented by human activities and formed small forest patches. All populations of this species remain in such small patches. Such populations are likely to be the results of inbreeding and an effect of genetic drift in subsequent generations.

Population structure and genetic relationships are important for establishing the appropriate scale and subunits for conservation management [35]. It is affected by mutation, gene flow, natural selection and genetic drift [36-37]. The STRUCTURE analysis suggested two different clusters among 80 studied individuals. Similarly, UPGMA analysis based on Nei's chord distance using POPTREE2 identified two clusters. This indicates that geography has effects on genetic structure of $D$. elatum. Based on our results, effective management strategies for $D$. elatum should include both in-situ and ex-situ conservations. Ex-situ conservation of $D$. elatum could be immediately implemented. It will be a protective and managed site to grown this species and prevent potential genetic erosion of wild D. elatum populations. Establishment of seed orchards from all the populations should secure genetic sources of D. elatum. 


\section{Conclusions}

The present study shows that the current situation of $D$. elatum maintains moderately high levels of genetic diversity and low levels of genetic differentiation among populations. The Bayesian analysis confirmed two main genetic groups with UPGMA dendrogram. The high genetic variation within individuals. Therefore, conservators should focus on maintaining the genetic variation within populations. These strategies should also be implemented with ex-situ conservation activities to avoid inbreeding in the future.

This research was financially supported by Russian-Vietnamese Tropical Center basis project, 20202022 and project E 1.2. We thank E. Sterling (New York) and K. Koy (Berkeley) for providing the map.

\section{References}

1. T.H. Nguyen, K.L. Phan, D.T.L. Nguyen, P.I. Thomas, A. Farjon, L. Averyanov, Viet Nam Conifers: Conservation Status Review 2004, Fauna \& Flora International, 92-93 (Vietnam Programme, Hanoi, 2004) (Vietnamese)

2. K.L. Phan, L. Phan, J. Regalado, L. Averyanov, B. Maslin, Pak J Bot, 49(5), 20372068 (2017)

3. M.P. Pham, V.H. Tran, D.D. Vu, Q.K. Nguyen, S.N.M. Shah, Czech J Genet Plant Breed, (2021) https://doi.org/10.17221/88/2020-CJGPB

4. D.D. Vu, T.T.X. Bui, M.T. Nguyen, D.G. Vu, M.D. Nguyen, X. Huang, Y. Zhang Y, J For Res, 28(2), 265-272 (2017)

5. D.D. Vu, T.T.X. Bui, M.D. Nguyen, A.N.M. Shah, D.G. Vu, Y. Zhang, M.T. Nguyen, X.H. Huang, J For Res, 30(5), 1821-1831 (2019)

6. M.T. Nguyen, D.D. Vu, P.H. Dang, T.T.X. Bui, P.L.H. Nguyen, M.D. Nguyen, Planta, 253, 66 (2021)

7. M.T. Nguyen, D.D. Vu, M.D. Nguyen, P.H. Dang, K.L. Phan, X.P. Bui, J Forest Res, 15(3), 198-201 (2020)

8. R.K. Varshney, A. Graner, M.E. Sorrells, TRENDS Biotechnol, 23, 48-55 (2005)

9. A.Y. Larionova, A.K. Ekart, A.N. Kravchenko, Eurasian J For Res, 10, 185-192 (2007)

10. R.K. Kalia, M.K. Rai, S. Kalia, R. Singh, A. Dhawan, Euphytica, 177, 309-334 (2011)

11. R. Mellick, C. Porter, M. Rossetto, Mol Ecol Res, 9(6), 1460-1466 (2009)

12. Y. Miao, X. Lang, S. Li, J. Su, Y. Wang, Int J Mol Sci, 13, 11165-1117 (2012)

13. K.H. Hung, C.Y. Lin, C.C. Huang, C.C. Hwang, T.W. Hsu, Y.L. Ku, W.K. Wang, C.Y. Hung, T.Y. Chiang, Botanical Studies, 53, 191-196 (2012)

14. Y.J. Su, T. Wang, F. Deng, Biochem Syst Ecol, 38(4), 576-584 (2010a)

15. Y.J. Su, T. Wang, F. Deng, Aust J Bot, 58(4), 318-326 (2010b)

16. T. L. Tran, T.T.H. Vu, T.L. Nguyen, T.P. Dinh, Vietnam J Biotechnol: 15(2), 293-305 (2017) (Vietnamese) 
17. D.D. Vu, S.N.M. Shah, M.P. Pham, V.T. Bui, M.T. Nguyen, T.P.T. Nguyen, BMC Plant Biology, 20, 358 (2020)

18. G.G. Vendramin, L. Lelli, P. Rossi, M. Morgante M, Mol Ecol 5, 595-598 (1996)

19. C.G. Elsik, V.T. Minihan, S.E. Hall, A.M. Scarpa, C.G. Williams, Genome, 43, 550555 (2000)

20. R. Peakall, P.E. Smouse, Bioinformatics, 28, 2537-39 (2012)

21. F. Rousset, Genepop'007: a complete re-implementation of the genepop software for Windows and Linux (2008).

22. L. Excoffier, G. Laval, S. Schneider, Evol Bioinform Online, 1, 47-50 (2005)

23. N. Takezaki, M. Nei, K. Tamura, Molecular Evolution, 27, 747-752 (2010)

24. J.K. Pritchard, M. Stephens, P. Donnelly, Genetics. 155(2), 945-959 (2000)

25. D.A. Earl B.M. von-Holdt, Conservation Genet Resour, 4, 359-361 (2012)

26. G. Evanno, S. Regnaut, J. Goudet, Mol Ecol, 14, 2611-2620 (2005)

27. A. Terrab, O. Paun, S. Talavera, K. Tremetsberger, M. Arista, T.F. Stuessy, Am J Bot 9, 1274-1280 (2006)

28. M. Dubreuil, F. Sebastiani, M. Mayol, S.C. Gonza'lez-Martınez, M. Riba, G.G. Vendramin, Conserv Genet 9, 1665-1668 (2008)

29. J.B. Yang, H.T. Li, D.Z. Li, J. Liu, L.M. Gao, Hort Science, 44(7), 2043-2045 (2009)

30. H. Xue, C.H. Lu, X.B. Wu, Genet Mol Res, 11(2), 1296-1299 (2012)

31. T.P. Dinh, T.L. Tran, T.T.H. Vu, T.H Nguyen, Genet Mol Res, 14(3), 7727-7739 (2015)

32. K.C. Rai, H.S. Ginwal, Silvae Genetica, 67, 99-105 (2018)

33. Y.C. Miao, J.R. Su, Z.J. Zhang, H. Li, J. Luo, Y.P. Zhang, Conserv Genet, 9, 16831685 (2008)

34. M.T. Nguyen, D.D. Vu, T.T.X. Bui, M.D. Nguyen, Indian J Biotechnol, 12(4), 499503 (2013)

35. R. Ferrière, U. Dieckmann, D. Couvet, Evolutionary Conservation Biology (2004)

36. M.D. Loveless, J.L. Hamrick, Annu Rev Ecol Syst, 15, 65-95 (1984)

37. J. Schneller, B. Liebst, Am J Bot, 94(6), 965-71 (2007) 